\title{
Bone marrow micro-environment is a crucial player for myelomagenesis and disease progression
}

\author{
Patrizia Mondello',2,3, Salvatore Cuzzocrea ${ }^{2}$, Michele Navarra² and Michael Mian ${ }^{4,5}$ \\ ${ }^{1}$ Department of Human Pathology, University of Messina, Messina, Italy \\ ${ }^{2}$ Department of Chemical, Biological, Pharmaceutical and Environmental Sciences, University of Messina, Messina, Italy \\ ${ }^{3}$ Lymphoma Service, Memorial Sloan Kettering Cancer Center, New York, NY, USA \\ ${ }^{4}$ Department of Hematology and Center of Bone Marrow Transplantation, Hospital of Bolzano, Bolzano/Bozen, Italy \\ ${ }^{5}$ Department of Internal Medicine V, Hematology \& Oncology, Medical University Innsbruck, Innsbruck, Austria \\ Correspondence to: Patrizia Mondello, email: patriziamondello@hotmail.it \\ Keywords: multiple myeloma, micro-environment, therapeutic opportunities, osteoclast activation, angiogenesis \\ Received: July 18, $2016 \quad$ Accepted: January 05, $2017 \quad$ Published: January 12, 2017
}

\section{ABSTRACT}

Despite the advent of many therapeutic agents, such as bortezomib and lenalidomide that have significantly improved the overall survival, multiple myeloma remains an incurable disease. Failure to cure is multifactorial and can be attributed to the underlying genetic heterogeneity of the cancer and to the surrounding microenvironment. Understanding the mutual interaction between myeloma cells and micro-environment may lead to the development of novel treatment strategies able to eradicate this disease. In this review we discuss the principal molecules involved in the micro-environment network in multiple myeloma and the currently available therapies targeting them.

\section{INTRODUCTION}

Multiple myeloma (MM) is a malignant lymphoproliferative disorder deriving from a clonal plasma cell dyscrasia with the ability to produce monoclonal immunoglobulins in most cases. The incidence of the disease has been estimated to be 26,850 new cases in 2015 in the United States. Disease occurrence increases with age, affecting mostly people in the sixth and seventh decade of life with a predominance in males and Afro-Americans [1]. Clinical presentation at onset is highly variable ranging from a completely asymptomatic disease without evidence of end-organ damage to an acute life threatening condition.

Despite intensive research, the etiology of MM is largely unknown. Possible risk factors include exposure to ionizing radiation, chemicals such as benzene, asbestos, lucite and antigens. Also genetic factors play a major role [2]. Transformation of a normal plasma cell into a neoplastic cell is a multistep process [3] due to genetic and molecular events [4] as well as to important and irreversible alterations in the bone marrow microenvironment $[5,6]$. The myeloma cell is immersed in the bone marrow micro-environment where it mutually interacts with stromal cells (BMSC), osteoblasts, osteoclasts, lymphocytes and endothelial cells [6] (Figure 1). Indeed, culture of plasma cells is only possible in the presence of BMSC [6].

A process of major importance is the interaction between myeloma cells and BMSC through adhesion molecules, such as VLA-4 and LFA-1. These interactions trigger a complex cytokine network between cancer cells and micro-environment, ultimately impacting further development and prognosis of the disease itself. Another system interaction involves $C-X-C$ chemokine ligand (CXCL)-12, expressed by BMSC, and its receptor $C-X-C$ chemokine receptor (CXCR)-4, located on MM cells, which is involved in motility and cytoskeletal rearrangements [6]. Moreover, CXCL-12 up-regulates transiently VLA-4, further influencing cellular adhesion of myeloma cells to the BMSC and cytokines secretion [7]. However, adhesion molecules are not the only players in this complex game: pathogenesis of MM also depends on the presence of growth factors $[8,9]$ that are usually produced by BMSC to regulate activity of lymphohemopoietic cells $[10,11]$.

In the present review, we focus on the pathogenetic mechanisms involving the bone marrow microenvironment and promoting myeloma. 


\section{INTERLEUKINE 6 (IL-6)}

IL-6 is produced by mononuclear phagocytes, endothelial cells, fibroblasts and many other cell types as a response to IL-1 and tumor necrosis factor (TNF). This molecule also stimulates the secretion of the proteins of the acute phase immune response, such as the protein or mannose-binding fibrinogen by the liver cells. IL-6 acts as a growth factor for activated B-cells and differentiation towards the plasma cell line and has multiple effects on hematopoietic and other cells [12]. It is closely involved in the pathogenesis of MM: 1) IL-6 induces in vitro growth of fresh cells isolated from myeloma patients; 2) The myeloma cells spontaneously produce IL-6 and express the corresponding receptor; 3 ) antibodies against IL-6 inhibit the growth of myeloma cells; 4) treatment of myeloma patients with antibodies against IL-6 has shown anti-tumor effect $[9,13,14]$; 5) retinoic acid induces apoptosis in myeloma cells by down-regulation expression of the IL-6 receptor [15]. Preliminary data suggests that the secretion of IL-6 is regulated by plasmoblast cytokines, such as
TNF-alpha and transforming growth factor (TGF)-beta [9].

Enhancing sensitivity of the myeloma cell to IL-6 contributes to the growth and expansion of the neoplastic cells, as is the case with the soluble receptors for IL-6 (sIL-6R) [16]. These receptors derive from cleavage of the receptor itself or from alternative splicing mechanisms of the respective RNA [17, 18]. sIL-6R is present in the serum and urine of healthy individuals [9], but it is significantly elevated in MM patients [16, 19-22]. Therefore, the significance of sIL -6R is controversial. Unlike other Authors [16, 20, 22], Ohtani et al. [19] observed a good correlation between sIL-6R levels and tumor burden. This is in line with the observation that elevated serum levels of IL-6 as well as its soluble receptor are able to predict a poor prognosis and to reflect the level of disease activity $[16,23,24]$, whereas the decrease of these parameters is associated with a good response to treatment [20].

Interaction between MM cell and BMSCs stimulates IL-6 secretion [25]. Originally identified as a regulator of normal B-cell differentiation, IL-6 has shown to promote

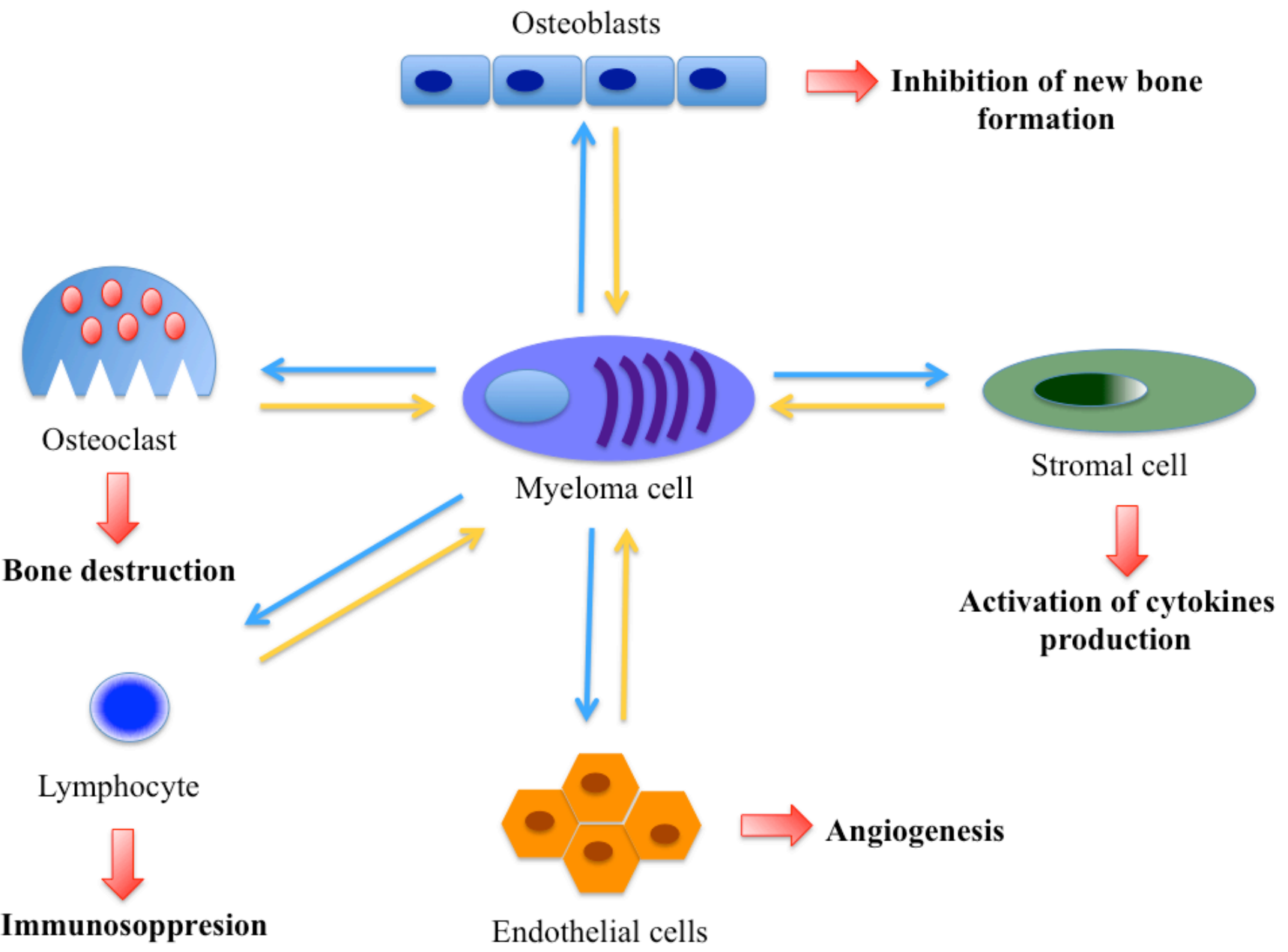

Figure 1: Interplay between various micro-environmental cells promoting angiogenesis and proliferation in multiple myeloma. 
myeloma cell proliferation and protect cells from apoptosis [26]. After co-culture with BMSCs, MM cells increased levels of phosphorylated AKT and ERK $[27,28]$, cyclin D2, CDK4, and Bcl-XL, and decreased cleaved Caspase3 and PARP [29], which are important signaling pathways involved in proliferation and apoptosis of MM cells.

Furthermore, IL-6 contributes to the dysfunction of immunosystem. In MM patients dendritic cells (DCs) presented a lower expression of HLA-DR, CD40 and CD80 antigens, and impaired activation of T-cell proliferation compared with controls. These DCs were unable to present the specific tumor antigen to autologous T cells [30]. Hwang et al demonstrated that the IL-6R $\alpha$ knockdown-DC vaccine significantly enhances the frequency of tumor-specific CD8+ producing effector molecules such as IFN- $\gamma$, TNF- $\alpha$, FasL, perforin, and granzyme $\mathrm{B}$, and generates more memory $\mathrm{T}$ cells, resulting in prolonged survival [31].

Finally, IL-6 is also produced by osteoclasts. These cells produce high levels of IL-6 when grown in co- culture with MM cells, resulting in further increase of cell proliferation and inhibition of apoptosis [32, 33]. Although its precise role is still under debate, IL-6 released by osteoclasts seems to increase MM tumor burden, and enhance bone destruction since it increases production of IL-17 by T-cells. Increased IL-17 secretion by these bone marrow $\mathrm{T}$ cells results in up-regulation of RANKL and increases osteoclast formation [34]. Expression of the IL17 receptor on MM plasma cells leads to IL-17 mediated growth of plasma cells [35].

Overall, therapies against IL-6 would be a rational target. Siltuximab is a monoclonal antibody (Ab) against IL-6, which has demonstrated to have a good safety profile (NCT01484275) [36]. Therefore, it was evaluated in transplant-ineligible MM patients in combination with bortezomib, melphalan, and prednisone (VMP). However, Siltuximab did not demonstrate an improvement in terms of complete response rate when compared to the VMP alone [37]. Since IL-6 is involved in early myelomastroma interaction and survival of neoplastic cells, IL-6

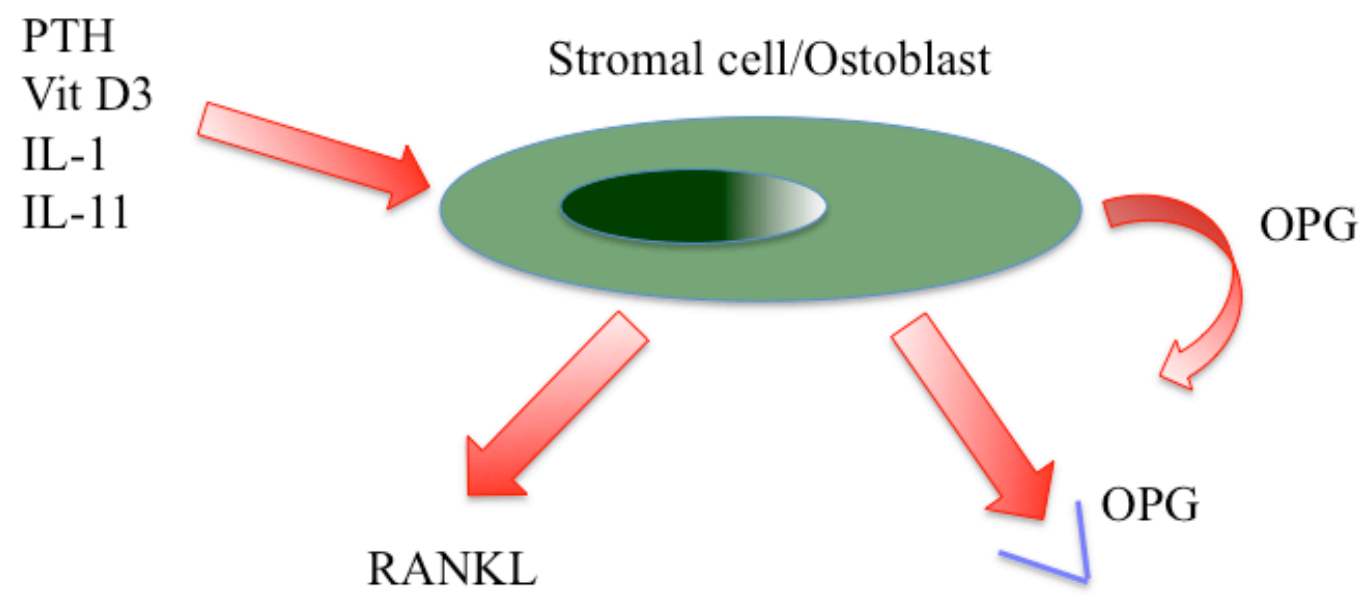

Lymphocyte T

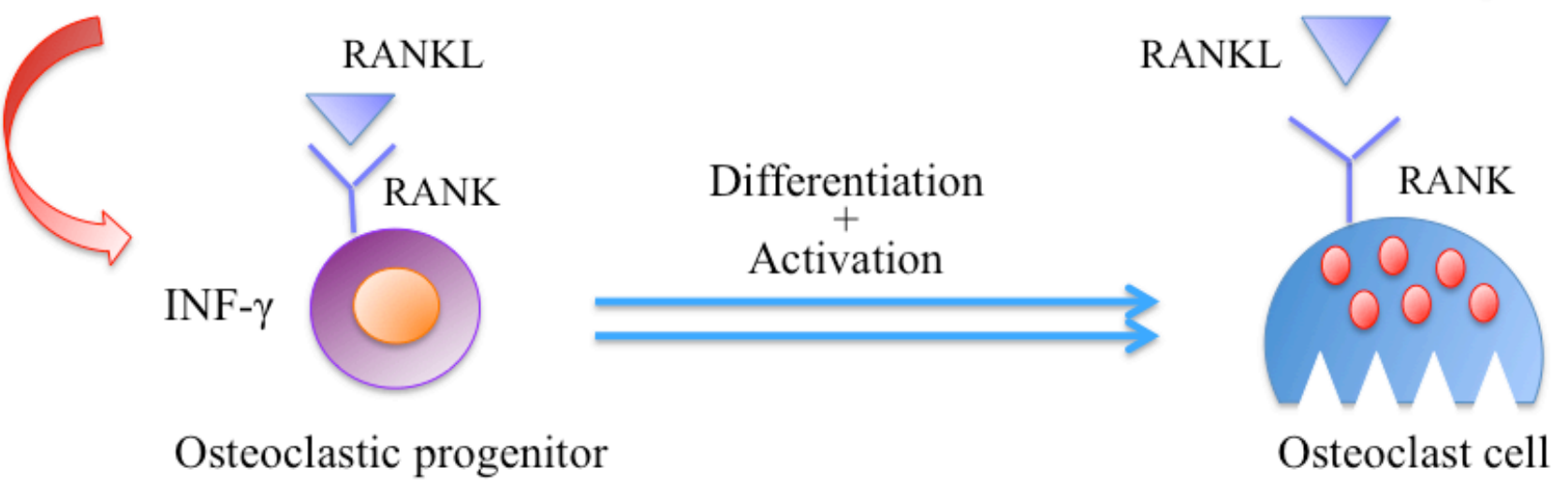

Figure 2: Bone remodelling in multiple myeloma. Myeloma cells also directly promote osteoclast formation via the endogenous expression of RANKL, and downregulation of the RANKL decoy receptor (OPG). 
therapy at earlier stages of the disease might be more beneficial. Therefore, Siltuximab is currently under investigation in patients with asymptomatic disease (NCT01484275).

\section{OSTEOCLAST ACTIVATION}

Osteoclast activation contributes to the decrease of bone matrix and ultimately to osteolysis. In normal conditions, osteoclast differentiation and activation are controlled by stromal cell/osteoblast through the Receptor Activator of NF- $\mathrm{kB}$ Ligand $(R A N K-L) / \mathrm{RANK} /$ osteoprotegerin (OPG) system [38-41]. Osteocytes are the major source of the osteoclastogenic cytokine RANK-L $[42,43]$. The specific receptor of this protein, RANK, is located on osteoclast progenitors and its stimulation leads to differentiation into mature and active osteoclasts [40, $41,44]$. RANK-L activity is physiologically countered by interferon-gamma (INF $\gamma$ ), which regulates osteoclast formation by preventing excessive bone resorption [3941].

In MM, RANK expression is dysregulated in osteoclast precursor cells [45]. Myeloma cells also directly promote osteoclast formation via the endogenous expression of RANK-L [45], TNF- $\alpha$, and macrophage inflammatory protein 1 alpha (MIP-1 $\alpha$ ) [46-50]. Myeloma cells further contribute to osteoclastogenesis by downregulating expression of the RANK-L decoy receptor (OPG) [51, 52]. (Figure 2) This inhibitory effect is secondary to the interaction of myeloma cells and BMSC through VLA4 and VCAM1 [47, 53]. Preclinical studies have supported the importance of the RANK-L/OPG in the pathogenesis of bone lesions in MM. In xenograft model, treatment with either OPG or inhibitor of the receptor RANK inhibited bone lysis and reduced the osteoclasts number [54]. Furthermore, inhibition of this receptor resulted in decreasing of tumor burden and paraprotein levels in MM. Elevated levels of IL-6 induce RANK-L expression also in lymphocytes and decrease INF $\gamma$ production [55], leading to bone resorption. Ultimately, there is an imbalance of osteoclast homeostasis in favor of RANK-L and to the detriment of OPG and INF $\gamma$, resulting in osteoclast activation, bone resorption and myeloma cell survival [56].

Therefore, bisphosphonates and monoclonal antibodies binding RANK-L are commonly used to limit osteoclast activity [57, 58]. These therapies significantly delay skeletal-related events such as pathological fracture and therefore reduce disease-associated morbidity [59, 60], and prolong survival [61-63].

Osteoblast-mediated bone formation/mineralization is significantly reduced in MM patients, contributing to bone destruction. The factors involved in osteoblast suppression have been widely described within the Wnt pathway and myeloma-derived factors [64]. Many therapeutic agents that increase bone formation or block agonists in myeloma patients are currently under investigation. These include potent osteogenic factors such as Wnt, Dickkopf Wnt signaling pathway 1 (DKK1), fibroblast growth factor (FGF) 23 , and heparanase [65-67]. In xenograft model, the DKK-1 inhibitor BHQ880 increased osteoblast number and trabecular bone volume [68]. Similarly, using this drug combined with bisphosphonate resulted in a trend towards increased bone mineral density in relapsed MM [69]. Other phase I/ II clinical trials examining its efficacy are completed with pending reports (NCT01302886, NCT00741377, and NCT01337752).

\section{CD28}

CD8 + T cells recognize and eliminate cells infected by intracellular pathogens [70] as well as neoplastic cells [71]. The T-cell receptor (TCR) identifies such cells by interaction with MHC-I-receptor and the bound peptide antigen presented on the surface of antigen-presenting cells (APCs), namely DCs and macrophages/monocytes [72]. However, the stimulation via TCR alone is not sufficient to activate the CD8+ $\mathrm{T}$ cells [73-75] since a co-stimulatory signal is necessary [75]. One of the best characterized co-stimulus is the interaction of $\mathrm{CD} 28$ of the T cell and CD86 or CD80 of the APC $[72,73]$. Persistent antigenic stimulation or repetitive stimulation/ proliferation rounds lead to progressively down-regulation of CD28 expression and accumulation of highly antigen experienced CD8+ CD28 T cells [72, 74]. The decrease of CD28 is associated with the increased expression of CD57 (HNK, Leu-7, L-2) [76, 77], a terminally sulphated carbohydrate-determinant found on various surface glycoproteins, proteoglycans and glycolipids on subsets of natural killer (NK) cells, T cells, and others $[72,78,79]$.

High levels of CD8+ CD28- (CD8+ CD57+) T-cell population are associated with malignancy. Increased number of these $\mathrm{T}$ cells was found both in the microenviroment and peripheral blood of patients with solid tumors [71, 80-83] and hematologic malignancies [8488]. Patients affected by melanoma showed the expanded CD8+ CD28- $\mathrm{T}$ cells with high perforin expression, suggesting an active immune response against the tumor [81]. Conversely, lung cancer patients presented expanded CD8+ CD28- T cells with significant levels of FOXP3 + , which were attributed to the immunosuppressive component of the antitumour immune response [82]. Probably the predominance of cytotoxic versus immunosuppressive $\mathrm{CD} 8+\mathrm{CD} 28$ - $\mathrm{T}$ cell population differs in various types of cancer or even between individual patients with the same oncological disease.

\section{CD38}

CD38 is a multifunctional cell surface protein that has receptor [89] as well as enzyme functions [90, 91] 
with an important role in cell signaling. This protein is found at high levels on normal plasma cells as well as in hematological malignancies [92-98]. CD38 levels are even higher in malignant plasma cells [99], which is why it is an attractive therapeutic target for MM. Various antiCD38 antibodies have been developed and up to now available preclinical and clinical data are very promising. The so far best investigated antibody is Daratumumab. This IgG1 antibody binds a unique epitope present on the CD38 molecule leading to complement-dependent cytotoxicity [100]. Furthermore, Daratumumab decreases the CD38+ immunosopressive cellular population, increases T-helper and cytotoxic T-cells population, and enhances TCR clonality [101]. In vivo daratumumab alone showed substantial tumor cell lysis. This effect markedly increased, when the antibody was combined with anti-myeloma drugs, such as lenalidomide and bortezomib [102, 103]. Its clinical efficacy was evaluated in the CASTOR and Pollux trial [104, 105]. The former included nearly 500 relapsed or refractory multiple myeloma patients, each of whom underwent eight cycles of a standard two-drugs induction regimen (bortezomib and dexamethasone). Afterwards they were randomized to receive daratumumab maintenance therapy or not. In interim analysis, daratumumab combination reduced the risk of cancer progression by $70 \%$, and doubled both rates of very good partial response from $29 \%$ to $59 \%$ and complete response from $9 \%$ to $19 \%$ with a manageable toxicity profile [104]. Also in the POLLUX trial, in which 569 relapsed or refractory patients were treated with daratumumab in combination with lenalidomide and dexamethasone, the addition of the antibody significantly prolonged progression-free survival (PFS) $(p<0.0001)$

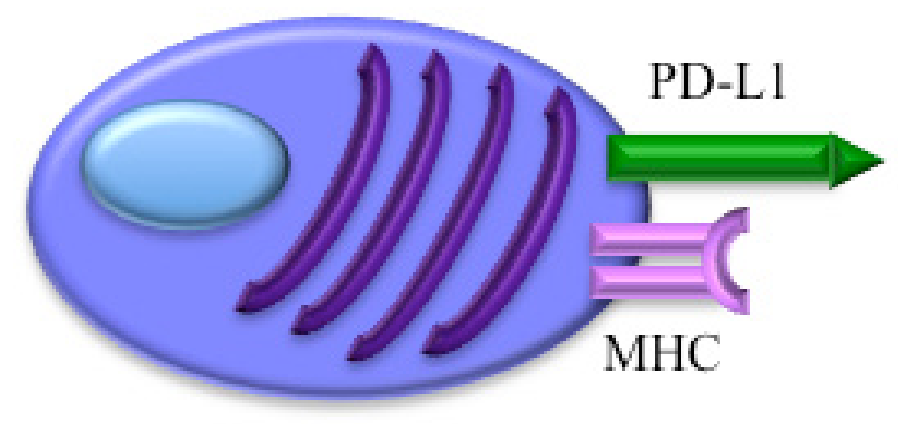

Myeloma cell and reduced the risk of disease progression of $63 \%$ [105]. Based on these promising results, Daratumumab was approved by the U.S. Food and Drug Administration as the first monoclonal antibody for the treatment of multiple myeloma.

Currently, there are ongoing phase 3 studies, which include daratumumab in combination with either lenalidomide or bortezomib-based regimens in newly diagnosed MM (NCT02252172, NCT02195479, and NCT02541383). An additional phase 1 study is also investigating the subcutaneous delivery of daratumumab in association with recombinant human hyaluronidase in patients with relapsed/refractory MM (NCT02519452).

\section{PD-1 AND PD-L1}

Tumors can escape immunosurveillance by expression of molecules that inhibit antitumor immunoresponse, such as programmed cell death ligand 1 (PD-L1) [106]. Although PD-L1 expression has not been observed in normal epithelial cells, it is highly expressed on many solid tumors [107]. PD-1 is a cell surface receptor of the immunoglobulin superfamily and is expressed on $\mathrm{T}$ cells, B cells, and NK cells [108]. Within the tumor, cells of the micro-environment express PD-L1, leading to T cell anergy upon cellular contact. (Figure 3) Furthermore, T cells produce INF $\gamma$, which upregulates PD-L1 expression on tumor and infiltrating immune cells, forming a feedback loop that generates a PD-1 signal maintaining immunosuppression [109, 110]. Although not detected on normal plasma cells, myeloma cell lines and primary myeloma cells up-regulate PD-L1, while its ligand PD-1 is found on a proportion of T-cells in myeloma patients

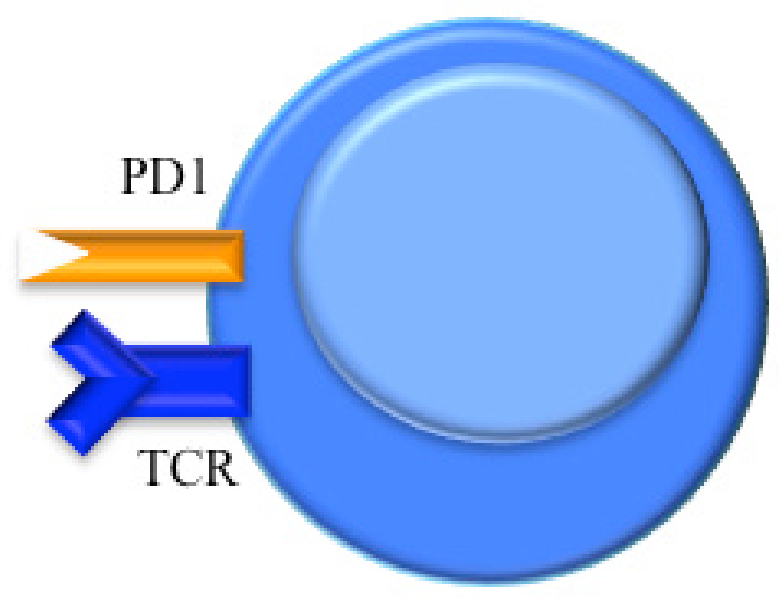

$\mathrm{T}$ cell

Figure 3: Binding of PD-1 on the T cell with tumor-associated PD-L1 results in downregulation of T-cell effector functions. 
[111-115]. The highest PD-L1 expression levels were detected in relapsed/refractory MM and correlated with tumor burden and poor treatment response [107]. AntiPD-L1 antibodies inhibit dendritic cells and myeloidderived suppressor cells enhancing the cytolytic activity of NK cells against MM cell [114]. Phase I studies using checkpoint inhibitors reported disappointing results, achieving stable disease as best response [116, 117]. Nevertheless, combination treatments including these checkpoint inhibitors could lead to an increased anti-MM host immunity and therefore better clinical responses. Clinical trials investigating the combination of anti-PD-L1 treatment with either immunomodulatory agents, such as lenalidomide (NCT02077959), myeloma vaccines (e.g., NCT01067287), or other T-cell co-inhibitor molecules such as cytotoxic T-lymphocyte-associate protein 4 (NCT01592370), which modulate MM-host immune responses, are ongoing.

\section{ANGIOGENESIS AND ANGIOGENIC FACTORS}

In 1999 Vacca et al described an increased neovascularization of the bone marrow stroma in patients affected by MM [118]. The grade of this neovascularization seems to increase during the evolution from monoclonal gammopathy of undetermined significance (MGUS) to MM [119]. This process is triggered by neoangiogenetic factors, which are produced from the BMSC, [such as vascular endothelial growth factor (VEGF), basic fibroblasr growth factor (b-FGF) and TGF- $\beta$, and from the myeloma cells themselves (such as VEGF, IL-8 and TGF- $\beta$ ). (Figure 4)

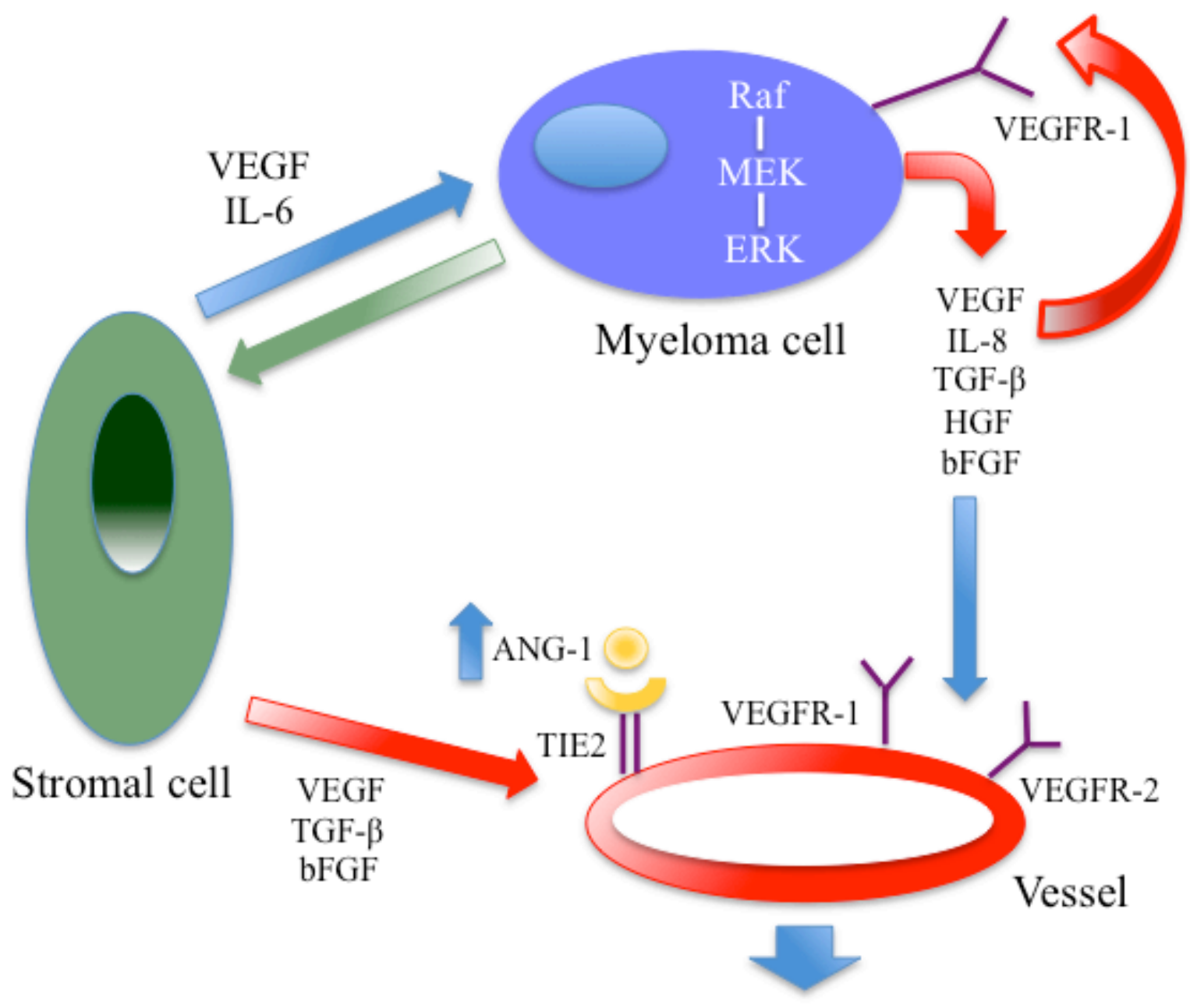

\section{Angiogenesis}

Figure 4: Autocrine and paracrine VEGF-mediated pathways in multiple myeloma: both are important for tumor angiogenesis and growth. A close relationship between VEGF and IL-6 has been found in the paracrine pathways. 


\section{Vascular endothelial growth factor (VEGF)}

The VEGF is the major pro-angiogenic molecule. It has a key role in regulating physiological as well as pathological angiogenesis $[120,121]$. Up to now, four genes structurally related to VEGF have been identified. Among their known products, there are placenta growth factors (PGF) [122-124], VEGF-a, VEGF-b [124], VEGF-c [125],VEGF-d [126] and VEGF-e [126]. The VEGF-a isoform is the most important VEGF molecule contributing to MM since its receptor, VEGFR-2, is highly expressed on plasma cells and endothelial cells in MM [127, 128]. After stimulation of VEGFR-2, mitogenactivated protein (MAP)-kinase is phosphorylated, resulting in an enhanced cell proliferation. Probably there is a paracrine mechanism behind the VEGF-induced stimulation of the endothelium: the plasma cell secretes VEGF-a, which binds to the VEGFR-2 on angiopoietic cells, ultimately activating a proliferative signal.

VEGF-a is also an important communication signal between stromal and myeloma cells, inducing the microenvironment to produce the same VEGF, but also other proangiogenic factors, such as FGF- $\beta$ and TGF- $\beta$ [129]. Furthermore, VEGF-a has an autocrine effect on the neoplastic cell, mediated by VEGFR-2 and the intracellular transmission pathway RAF-1/MEK-1, which would strengthen further angiogenic stimulus [129].

In tumors, hypoxia may be a consequence of the distance of the growing tumor cells from existent capillaries or inefficiency of the new vessels $[130,131]$. Therefore, the expression of VEGF and its receptor is induced in angiopoietic cells in order to avoid cell death. Apart from the stimulation of neovascularization and the increase of production of cytokines and proteolytic enzymes contributing to neo-angiogenesis, VEGF leads to upregulation of some proto-oncogenes typically found in MM, such as V-ras, K-ras, V-raf, Src and Fos [132]. Indeed, inhibition of VEGFR-2 and VEGF-a reduces myeloma clone proliferation. Patients with MM have low levels of semaforina III, which has a physiological antiangiogenic effect, balancing the action of VEGF [133]. Microvascular density of the bone marrow assessed with anti CD34 and DC15 (which are antigens present on the endothelium) is increased in patients with MM compared to healthy controls and also seems to correlate with the stage of disease. Of note, although bone marrow vascularization appears to be a prognostic marker, it does not change after therapy [134]. Another important question is related to the measurable levels of the signaling proteins as well as their receptors. For example, Dales et al have demonstrated an increased expression of VEGF-R1 in diseases such as breast cancer, a disease in which VEGF-R1 seems to be a negative prognostic marker with a high risk of metastases and relapses [135] and the use of antibodies against VEGF-R1 determines a powerful inhibition of neoplastic cell growth [136].
Overall, drugs targeting mechanisms involving the various VEGF forms are promising targets for new treatment approaches. For example, Bevacizumab targets and blocks VEGF and VEGF's binding to its receptor on the vascular endothelium [137] and has demonstrated to be effective when used alone, and in combination with radiation in earlier preclinical studies [137, 138]. It is currently being studied clinically in many solid and blood tumors including primary systemic amyloidosis and MM [139, 140]. NCI's Cancer Therapy Evaluation Program sponsored a phase II study of bevacizumab plus thalidomide in MM. The study was closed early due to poor accrual. Combination therapy, in this limited sample, yielded similar results to single agent thalidomide. The small number of patients prevents correlation of VEGF or VEGFR1/VEGFR2 expression with response [141].

\section{Angiopoietins (Ang)}

Angs, consisting of 4 structurally related proteins, termed Ang-1, 2, and 4, are ligands for the vascularspecific tyrosine kinase TIE-2 receptor located on endothelial cells. Ang-1 and Ang-4 behave as activating ligands for Tie-2, whereas Ang-2 and Ang-3 function as competitive antagonists. When bound to Tie-2, Ang1 stimulates maturation and stabilization of the vascular wall [142, 143]. In contrast, Ang-2 antagonizes Tie-2 binding and induces vessel destabilization, leading to the angiogenic sprouting [144]. In MM Ang-1 and Ang2 , along with VEGF, possess an important role in the initiation of tumor angiogenesis [145]. This is further confirmed by the observation that tumor angiogenesis can be prevented using both antibodies against Ang-1 and VEGF-a, while neutralizing only either VEGF-a or Ang1 reduces it partially [146]. Ang-2 serum levels, alone or in ratio with Ang-1, are importantly prognostic for response to therapy and mainly for survival [147]. These data highlight the role of the angiopoietins pathway in the biology of MM, which could be an interesting target for new anti-myeloma agents.

\section{Platelet-derived growth factor -beta (PDGF- $\beta$ )}

PDGF-beta is able to up-regulate the expression of the protein c-MYC, thus reducing the sensibility of cancer cells to melphalan treatment. Additionally, melphalanresistant patients have an overexpression of c-MYC and higher levels of $P D G F-\beta$ [148]. The latter correlated with disease burden (estimated by Durie-Salmon staging system, levels of IL-6 and beta-2-microglobulin) [149, 150]. Therefore, compounds targeting this mechanism could improve MM treatment. PTK787/ZK22258 (PTK/ $\mathrm{ZK}$ ) is a potent tyrosine kinase inhibitor of both vascular endothelial growth factor receptor 1 (VEGF-R1) and VEGF-R2, and also inhibits the tyrosine kinase activity 
of PDGFR- $\beta$, Flt-4, c-kit and c-fms, although with less potency [133]. PTK/ZK inhibits endothelial cell migration and proliferation without cytotoxic or antiproliferative effects on cells that do not express VEGF receptors [133]. Oral administration of PTK/ZK at a dose of 25 $100 \mathrm{mg} / \mathrm{kg} /$ day decreases tumor growth in human cancer xenografts $[133,151]$. Overall, PTK/ZK inhibits multiple essential signaling pathways involved in proliferation and fibrogenesis [152], which is why this molecule could improve the efficacy of existing MM treatments.

\section{Fibroblast growth factor beta}

FGF-beta is able to trigger neovascularization in MM bone marrow [153]. In the altered microenvironment, the myeloma cells appear to be the main source of FGF-beta, which is why their expression levels could correlate with disease burden and therefore could be an important prognostic parameter for MM [154]. In fact, the concentration of FGF-beta is considerably increased in plasma cell lysates in the bone marrow and in peripheral blood of myeloma patients [154].

Apart from the pro-angiogenic effects of this growth factor, paracrine interactions between tumor cells and BMSC were observed: stimulation of stromal cells with FGF-beta induces an increase of IL-6 secretion. This process can be completely abrogated by the administration of antibodies against FGF-beta. On the other hand, stimulation with IL-6 increases the expression and secretion of FGF-beta by the myeloma cell lines [155].

\section{Matrix metallopeptidase (MMP)-1, MMP-2 and MMP-9}

The expression of these metal proteinases is considerably increased in myeloma plasma cells as well as cells of the tumor environment, such as macrophages, fibroblasts and osteoblasts [156, 157]. Up to now their role in the context of tumor angiogenesis is unclear, but they probably are mediators for VEGF and PDGF-betadependent mechanisms. Indeed, in vivo studies in murine models indicate that zoledronic acid is able to inhibit the expression of MMP-9 of macrophage origin and finally neoangiogenesis [158].

Increased levels of the MMP-1 has been associated with an enhanced capacity to degrade collagen I [159]. In MMP-1 transgenic mice, the synthesis of the latent form of collagenase leads to extracellular matrix degradation [160]. MMP-2 instead directly modulates tumor invasion [161], favoring the spreading of myeloma cells. The mechanisms responsible for the upregulation of MMP activity remain to be elucidated.

Overall, the most important mechanisms in MM are the production of MMP-9, activation of MMP-2 and induction of MMP-1 by the neoplastic cells, since they are major players for bone resorption and tumor spreading. Some inhibitors of MMPs are now available. In arthritis, these inhibitors lead to a dramatic suppression of cartilage and bone destruction [162]. In cancer, the MMP inhibitor Batimastat was effective in a variety of murine tumor metastatic models and was successfully used in patients with malignant ascites [163] and malignant pleural effusion [164].

\section{OTHERS FACTORS}

\section{Granulocyte colony stimulating factor (G-CSF)}

G-CSF is a hematopoietic growth factor with several similarities to IL-6 [165, 166]. Both IL-6 and G-CSF induce the activation of NF-IL-6, which is involved in the synthesis of the IL-6 [167]. In vivo G-CSF appears to be a potent growth factor for myeloma cells [9]. Despite their well-known physiological functions, G-CSF and IL-6 could modulate neutrophils in bone marrow, altering the activation potential of signaling pathways in neutrophils, especially that of STAT3. Co-stimulation with G-CSF and IL-6 induced a higher level of phospho-STAT3 in neutrophils, stimulating angiogenesis and tumor growth [167].

\section{IL-10}

IL-10 is another important growth factor contributing to the pathogenesis of MM. IL-10 has been proven to inhibit various immune functions, such as macrophage activation, cytokine production, and antigen presentation [168], while it induces both plasma cell proliferation and angiogenesis in MM [169]. IL-10 is also involved in initiating and promoting other malignancies [170].

High levels of IL-10 secreted by T regulatory cells or produced from myeloma cells can modulate antitumor host immune response, including the abrogation of DCs function [171, 172]. Furthermore, IL-10 seems to induce chemo-resistance $[173,174]$. In particular, the serum concentration of IL-10 has been found much higher in MM patients than in normal healthy people, correlating with poor prognosis [175] and poor treatment response [175].

\section{CONCLUSIONS}

The herein presented data provide evidence that the bone marrow environment is a very important player in various biological processes of myeloma development. The involved mechanisms are very complex and not only limited to osteoblast and osteoclast dysfunction, but include pathologic immune processes as well as growth 
factor dysregulations. Thus, these findings are the basis for innovative treatment approaches. Clinical trials designed to target immune and stromal components of the microenvironment are ongoing and, in combination with other anti-myeloma agents, should get us closer to our ultimate objective of eradicating the disease.

\section{CONFLICTS OF INTEREST}

The authors have no conflicts of interest to disclose that could be perceived as prejudicing the impartiality of the research reported.

\section{GRANT SUPPORT}

This article was not supported by any grant from any funding agency in the public, commercial or not-forprofit sector.

\section{REFERENCES}

1. Siegel RL, Miller KD, Jemal A. Cancer statistics, 2016. CA Cancer J Clin. 2015; 66:7-30.

2. Sergentanis TN, Zagouri F, Tsilimidos G, Tsagianni A, Tseliou M, Dimopoulos MA, Psaltopoulou T. Risk Factors for Multiple Myeloma: A Systematic Review of MetaAnalyses. Clin Lymphoma Myeloma Leuk. 2015; 15: 563 77.e1-3.

3. Kuehl WM, Bergsagel PL. Molecular pathogenesis of multiple myeloma and its premalignant precursor. J Clin Invest. 2012; 122: 3456-63.

4. Chapman MA, Lawrence MS, Keats JJ, Cibulskis K, Sougnez C, Schinzel AC, Harview CL, Brunet J-P, Ahmann GJ, Adli M, Anderson KC, Ardlie KG, Auclair $\mathrm{D}$, et al. Initial genome sequencing and analysis of multiple myeloma. Nature. 2011; 471: 467-72.

5. Podar K, Richardson PG, Hideshima T, Chauhan D, Anderson KC. The malignant clone and the bone-marrow environment. Best Pract Res Clin Haematol. 2007; 20: 597612.

6. Podar K, Chauhan D, Anderson KC. Bone marrow microenvironment and the identification of new targets for myeloma therapy. Leukemia. 2009; 23: 10-24.

7. Hideshima T, Bergsagel PL, Kuehl WM, Anderson KC. Advances in biology of multiple myeloma: clinical applications. Blood. 2004; 104: 607-18.

8. Klein B, Bataille R. Cytokine network in human multiple myeloma. Hematol Oncol Clin North Am. 1992; 6: 273-84.

9. Klein B. Cytokine, cytokine receptors, transduction signals, and oncogenes in human multiple myeloma. Semin Hematol. 1995; 32: 4-19.

10. Clark SC, Kamen R. The human hematopoietic colonystimulating factors. Science. 1987; 236: 1229-37.

11. Sieff CA. Biology and clinical aspects of the hematopoietic growth factors. Annu Rev Med. 1990; 41: 483-96.

12. Akira S, Taga T, Kishimoto T. Interleukin-6 in biology and medicine. Adv Immunol. 1993; 54: 1-78.

13. Klein B, Zhang XG, Jourdan M, Content J, Houssiau F, Aarden L, Piechaczyk M, Bataille R. Paracrine rather than autocrine regulation of myeloma-cell growth and differentiation by interleukin-6. Blood. 1989; 73: 517-26.

14. Zhang XG, Bataille R, Widjenes J, Klein B. Interleukin-6 dependence of advanced malignant plasma cell dyscrasias. Cancer. 1992; 69: 1373-6.

15. Levy Y, Labaume S, Colombel M, Brouet JC. Retinoic acid modulates the in vivo and in vitro growth of IL-6 autocrine human myeloma cell lines via induction of apoptosis. Clin Exp Immunol. 1996; 104: 167-72.

16. Gaillard JP, Bataille R, Brailly H, Zuber C, Yasukawa K, Attal M, Maruo N, Taga T, Kishimoto T, Klein B. Increased and highly stable levels of functional soluble interleukin-6 receptor in sera of patients with monoclonal gammopathy. Eur J Immunol. 1993; 23: 820-4.

17. Lust JA, Donovan KA, Kline MP, Greipp PR, Kyle RA, Maihle NJ. Isolation of an mRNA encoding a soluble form of the human interleukin-6 receptor. Cytokine. 1992; 4: 96-100.

18. Müllberg J, Dittrich E, Graeve L, Gerhartz C, Yasukawa K, Taga T, Kishimoto T, Heinrich PC, Rose-John S. Differential shedding of the two subunits of the interleukin-6 receptor. FEBS Lett. 1993; 332: 174-8.

19. Ohtani K, Ninomiya H, Hasegawa Y, Kobayashi T, Kojima H, Nagasawa T, Abe T. Clinical significance of elevated soluble interleukin- 6 receptor levels in the sera of patients with plasma cell dyscrasias. Br J Haematol. 1995; 91: 11620.

20. Kyrtsonis MC, Dedoussis G, Zervas C, Perifanis V, Baxevanis C, Stamatelou M, Maniatis A. Soluble interleukin-6 receptor (sIL-6R), a new prognostic factor in multiple myeloma. Br J Haematol. 1996; 93: 398-400.

21. Papadaki H, Kyriakou D, Foudoulakis A, Markidou F, Alexandrakis M, Eliopoulos GD. Serum levels of soluble IL-6 receptor in multiple myeloma as indicator of disease activity. Acta Haematol. 1997; 97: 191-5.

22. Stasi R, Brunetti M, Parma A, Di Giulio C, Terzoli E, Pagano A. The prognostic value of soluble interleukin-6 receptor in patients with multiple myeloma. Cancer. 1998; 82: 1860-6.

23. Filella X, Blade J, Guillermo AL, Molina R, Rozman C, Ballesta AM. Cytokines (IL-6, TNF-alpha, IL-1alpha) and soluble interleukin-2 receptor as serum tumor markers in multiple myeloma. Cancer Detect Prev. 1996; 20: 52-6.

24. Merlini G, Perfetti V, Gobbi PG, Quaglini S, Franciotta DM, Marinone G, Ascari E. Acute phase proteins and prognosis in multiple myeloma. Br J Haematol. 1993; 83: 595-601.

25. Lauta VM. Interleukin-6 and the network of several cytokines in multiple myeloma: an overview of clinical and 
experimental data. Cytokine. 2001; 16: 79-86.

26. Yoshizaki K, Nakagawa T, Fukunaga K, Tseng LT, Yamamura Y, Kishimoto T. Isolation and characterization of $\mathrm{B}$ cell differentiation factor (BCDF) secreted from a human B lymphoblastoid cell line. J Immunol. 1984; 132: 2948-54.

27. Tu Y, Gardner A, Lichtenstein A. The phosphatidylinositol 3-kinase/AKT kinase pathway in multiple myeloma plasma cells: roles in cytokine-dependent survival and proliferative responses. Cancer Res. 2000; 60: 6763-70.

28. Ogata A, Chauhan D, Teoh G, Treon SP, Urashima M, Schlossman RL, Anderson KC. IL-6 triggers cell growth via the Ras-dependent mitogen-activated protein kinase cascade. J Immunol. 1997; 159: 2212-21.

29. Xu S, Menu E, De Becker A, Van Camp B, Vanderkerken $\mathrm{K}$, Van Riet I. Bone marrow-derived mesenchymal stromal cells are attracted by multiple myeloma cell-produced chemokine CCL25 and favor myeloma cell growth in vitro and in vivo. Stem Cells. 2012; 30: 266-79.

30. Ratta M, Fagnoni F, Curti A, Vescovini R, Sansoni P, Oliviero B, Fogli M, Ferri E, Della Cuna GR, Tura S, Baccarani M, Lemoli RM. Dendritic cells are functionally defective in multiple myeloma: the role of interleukin-6. Blood. 2002; 100: 230-7.

31. Hwang W, Jung K, Jeon Y, Yun S, Kim TW, Choi I. Knockdown of the interleukin-6 receptor alpha chain of dendritic cell vaccines enhances the therapeutic potential against IL-6 producing tumors. Vaccine. 2010; 29: 34-44.

32. Abe M, Hiura K, Wilde J, Shioyasono A, Moriyama K, Hashimoto T, Kido S, Oshima T, Shibata H, Ozaki S, Inoue D, Matsumoto T. Osteoclasts enhance myeloma cell growth and survival via cell-cell contact: a vicious cycle between bone destruction and myeloma expansion. Blood. 2004; 104: 2484-91.

33. Anderson $\mathrm{KC}$, Jones RM, Morimoto C, Leavitt P, Barut BA. Response patterns of purified myeloma cells to hematopoietic growth factors. Blood. 1989; 73: 1915-24.

34. Noonan K, Marchionni L, Anderson J, Pardoll D, Roodman GD, Borrello I. A novel role of IL-17-producing lymphocytes in mediating lytic bone disease in multiple myeloma. Blood. 2010; 116: 3554-63.

35. Prabhala RH, Pelluru D, Fulciniti M, Prabhala HK, Nanjappa P, Song W, Pai C, Amin S, Tai Y-T, Richardson PG, Ghobrial IM, Treon SP, Daley JF, et al. Elevated IL17 produced by $\mathrm{TH} 17$ cells promotes myeloma cell growth and inhibits immune function in multiple myeloma. Blood. 2010; 115: 5385-92.

36. Kurzrock R, Voorhees PM, Casper C, Furman RR, Fayad L, Lonial S, Borghaei H, Jagannath S, Sokol L, Usmani SZ, van de Velde H, Qin X, Puchalski TA, et al. A phase I, open-label study of siltuximab, an anti-IL-6 monoclonal antibody, in patients with B-cell non-Hodgkin lymphoma, multiple myeloma, or Castleman disease. Clin Cancer Res. 2013; 19: 3659-70.
37. San-Miguel J, Bladé J, Shpilberg O, Grosicki S, Maloisel F, Min C-K, Polo Zarzuela M, Robak T, Prasad SVSS, Tee Goh Y, Laubach J, Spencer A, Mateos M-V, et al. Phase 2 randomized study of bortezomib-melphalan-prednisone with or without siltuximab (anti-IL-6) in multiple myeloma. Blood. 2014; 123: 4136-42.

38. Anderson DM, Maraskovsky E, Billingsley WL, Dougall WC, Tometsko ME, Roux ER, Teepe MC, DuBose RF, Cosman D, Galibert L. A homologue of the TNF receptor and its ligand enhance T-cell growth and dendritic-cell function. Nature. 1997; 390: 175-9.

39. Lacey DL, Timms E, Tan HL, Kelley MJ, Dunstan CR, Burgess T, Elliott R, Colombero A, Elliott G, Scully S, Hsu $\mathrm{H}$, Sullivan J, Hawkins N, et al. Osteoprotegerin ligand is a cytokine that regulates osteoclast differentiation and activation. Cell. 1998; 93: 165-76.

40. Hsu H, Lacey DL, Dunstan CR, Solovyev I, Colombero A, Timms E, Tan HL, Elliott G, Kelley MJ, Sarosi I, Wang L, Xia XZ, Elliott R, et al. Tumor necrosis factor receptor family member RANK mediates osteoclast differentiation and activation induced by osteoprotegerin ligand. Proc Natl Acad Sci U S A. 1999; 96: 3540-5.

41. Simonet WS, Lacey DL, Dunstan CR, Kelley M, Chang MS, Lüthy R, Nguyen HQ, Wooden S, Bennett L, Boone T, Shimamoto G, DeRose M, Elliott R, et al. Osteoprotegerin: a novel secreted protein involved in the regulation of bone density. Cell. 1997; 89: 309-19.

42. Nakashima T, Hayashi M, Fukunaga T, Kurata K, OhHora M, Feng JQ, Bonewald LF, Kodama T, Wutz A, Wagner EF, Penninger JM, Takayanagi H. Evidence for osteocyte regulation of bone homeostasis through RANKL expression. Nat Med. 2011; 17: 1231-4.

43. Xiong J, Onal M, Jilka RL, Weinstein RS, Manolagas SC, O'Brien CA. Matrix-embedded cells control osteoclast formation. Nat Med. 2011; 17: 1235-41.

44. Fuller K, Wong B, Fox S, Choi Y, Chambers TJ. TRANCE is necessary and sufficient for osteoblast-mediated activation of bone resorption in osteoclasts. J Exp Med. 1998; 188: 997-1001.

45. Colombo M, Thümmler K, Mirandola L, Garavelli S, Todoerti K, Apicella L, Lazzari E, Lancellotti M, Platonova N, Akbar M, Chiriva-Internati M, Soutar R, Neri A, et al. Notch signaling drives multiple myeloma induced osteoclastogenesis. Oncotarget. 2014; 5: 10393-406. doi: 10.18632/oncotarget.2084.

46. Raisz LG, Luben RA, Mundy GR, Dietrich JW, Horton JE, Trummel CL. Effect of osteoclast activating factor from human leukocytes on bone metabolism. J Clin Invest. 1975; 56: 408-13.

47. Pearse RN, Sordillo EM, Yaccoby S, Wong BR, Liau DF, Colman N, Michaeli J, Epstein J, Choi Y. Multiple myeloma disrupts the TRANCE/ osteoprotegerin cytokine axis to trigger bone destruction and promote tumor progression. Proc Natl Acad Sci U S A. 2001; 98: 11581-6. 
48. Han JH, Choi SJ, Kurihara N, Koide M, Oba Y, Roodman GD. Macrophage inflammatory protein-1alpha is an osteoclastogenic factor in myeloma that is independent of receptor activator of nuclear factor kappaB ligand. Blood. 2001; 97: 3349-53.

49. Farrugia AN, Atkins GJ, To LB, Pan B, Horvath N, Kostakis P, Findlay DM, Bardy P, Zannettino ACW. Receptor activator of nuclear factor-kappaB ligand expression by human myeloma cells mediates osteoclast formation in vitro and correlates with bone destruction in vivo. Cancer Res. 2003; 63: 5438-45.

50. Heider U, Langelotz C, Jakob C, Zavrski I, Fleissner C, Eucker J, Possinger K, Hofbauer LC, Sezer O. Expression of receptor activator of nuclear factor kappaB ligand on bone marrow plasma cells correlates with osteolytic bone disease in patients with multiple myeloma. Clin Cancer Res. 2003; 9: 1436-40.

51. Giuliani N, Bataille R, Mancini C, Lazzaretti M, Barillé S. Myeloma cells induce imbalance in the osteoprotegerin/ osteoprotegerin ligand system in the human bone marrow environment. Blood. 2001; 98: 3527-33.

52. Seidel C, Hjertner $\varnothing$, Abildgaard N, Heickendorff L, Hjorth M, Westin J, Nielsen JL, Hjorth-Hansen H, Waage A, Sundan A, Børset M. Serum osteoprotegerin levels are reduced in patients with multiple myeloma with lytic bone disease. Blood. 2001; 98: 2269-71.

53. Roux S, Meignin V, Quillard J, Meduri G, GuiochonMantel A, Fermand J-P, Milgrom E, Mariette X. RANK (receptor activator of nuclear factor-kappaB) and RANKL expression in multiple myeloma. Br J Haematol. 2002; 117: 86-92.

54. Croucher PI, Shipman CM, Lippitt J, Perry M, Asosingh K, Hijzen A, Brabbs AC, van Beek EJ, Holen I, Skerry TM, Dunstan CR, Russell GR, Van Camp B, et al. Osteoprotegerin inhibits the development of osteolytic bone disease in multiple myeloma. Blood. 2001; 98: 3534-40.

55. Bataille R, Jourdan M, Zhang XG, Klein B. Serum levels of interleukin 6, a potent myeloma cell growth factor, as a reflect of disease severity in plasma cell dyscrasias. J Clin Invest. 1989; 84: 2008-11.

56. Viereck V, Emons G, Lauck V, Frosch K-H, Blaschke S, Gründker C, Hofbauer LC. Bisphosphonates pamidronate and zoledronic acid stimulate osteoprotegerin production by primary human osteoblasts. Biochem Biophys Res Commun. 2002; 291: 680-6.

57. Rogers MJ. From molds and macrophages to mevalonate: a decade of progress in understanding the molecular mode of action of bisphosphonates. Calcif Tissue Int. 2004; 75: 451-61.

58. Lipton A, Fizazi K, Stopeck AT, Henry DH, Brown JE, Yardley DA, Richardson GE, Siena S, Maroto P, Clemens M, Bilynskyy B, Charu V, Beuzeboc P, et al. Superiority of denosumab to zoledronic acid for prevention of skeletal-related events: a combined analysis of 3 pivotal, randomised, phase 3 trials. Eur J Cancer. 2012; 48: 3082
92.

59. Berenson JR, Lichtenstein A, Porter L, Dimopoulos MA, Bordoni R, George S, Lipton A, Keller A, Ballester O, Kovacs M, Blacklock H, Bell R, Simeone JF, et al. Longterm pamidronate treatment of advanced multiple myeloma patients reduces skeletal events. Myeloma Aredia Study Group. J Clin Oncol. 1998; 16: 593-602.

60. Henry D, Vadhan-Raj S, Hirsh V, von Moos R, Hungria V, Costa L, Woll PJ, Scagliotti G, Smith G, Feng A, Jun S, Dansey R, Yeh H. Delaying skeletal-related events in a randomized phase 3 study of denosumab versus zoledronic acid in patients with advanced cancer: an analysis of data from patients with solid tumors. Support Care Cancer. 2014; 22: 679-87.

61. McCloskey E V, Dunn JA, Kanis JA, MacLennan IC, Drayson MT. Long-term follow-up of a prospective, double-blind, placebo-controlled randomized trial of clodronate in multiple myeloma. Br J Haematol. 2001; 113: 1035-43.

62. Henry DH, Costa L, Goldwasser F, Hirsh V, Hungria V, Prausova J, Scagliotti GV, Sleeboom H, Spencer A, Vadhan-Raj S, von Moos R, Willenbacher W, Woll PJ, et al. Randomized, double-blind study of denosumab versus zoledronic acid in the treatment of bone metastases in patients with advanced cancer (excluding breast and prostate cancer) or multiple myeloma. J Clin Oncol. 2011; 29: 1125-32.

63. Wang X, Yan X, Li Y. A meta-analysis of the antitumor effect and safety of bisphosphonates in the treatment of multiple myeloma. Int J Clin Exp Med. 2015; 8: 6743-54.

64. Roodman GD. Osteoblast function in myeloma. Bone. 2011; 48: 135-40.

65. Kim J, Denu RA, Dollar BA, Escalante LE, Kuether JP, Callander NS, Asimakopoulos F, Hematti P. Macrophages and mesenchymal stromal cells support survival and proliferation of multiple myeloma cells. Br J Haematol. 2012; 158: 336-46.

66. Fukumoto S. FGF23-FGF Receptor/Klotho Pathway as a New Drug Target for Disorders of Bone and Mineral Metabolism. Calcif Tissue Int. 2016; 98: 334-40.

67. Ruan J, Trotter TN, Nan L, Luo R, Javed A, Sanderson RD, Suva LJ, Yang Y. Heparanase inhibits osteoblastogenesis and shifts bone marrow progenitor cell fate in myeloma bone disease. Bone. 2013; 57: 10-7.

68. Fulciniti M, Tassone P, Hideshima T, Vallet S, Nanjappa P, Ettenberg SA, Shen Z, Patel N, Tai Y-T, Chauhan D, Mitsiades C, Prabhala R, Raje N, et al. Anti-DKK1 mAb (BHQ880) as a potential therapeutic agent for multiple myeloma. Blood. 2009; 114: 371-9.

69. Iyer SP, Beck JT, Stewart AK, Shah J, Kelly KR, Isaacs R, Bilic S, Sen S, Munshi NC. A Phase IB multicentre dose-determination study of BHQ880 in combination with anti-myeloma therapy and zoledronic acid in patients with relapsed or refractory multiple myeloma and prior skeletal- 
related events. Br J Haematol. 2014; 167: 366-75.

70. Nagata T, Koide Y. Induction of Specific CD8 T Cells against Intracellular Bacteria by CD8 T-Cell-Oriented Immunization Approaches. J Biomed Biotechnol. 2010; 2010: 764542 .

71. Tsukishiro T, Donnenberg AD, Whiteside TL. Rapid turnover of the CD8(+)CD28(-) T-cell subset of effector cells in the circulation of patients with head and neck cancer. Cancer Immunol Immunother. 2003; 52: 599-607.

72. Arosa FA. CD8+CD28- T cells: certainties and uncertainties of a prevalent human T-cell subset. Immunol Cell Biol. 2002; 80: 1-13.

73. Bernard A, Lamy And L, Alberti I. The two-signal model of T-cell activation after 30 years. Transplantation. 2002; 73: S31-5.

74. Vallejo AN. CD28 extinction in human T cells: altered functions and the program of T-cell senescence. Immunol Rev. 2005; 205: 158-69.

75. Boesteanu AC, Katsikis PD. Memory T cells need CD28 costimulation to remember. Semin Immunol. 2009; 21: 69-77.

76. Merino J, Martínez-González MA, Rubio M, Inogés S, Sánchez-Ibarrola A, Subirá ML. Progressive decrease of CD8high+ CD28+CD57- cells with ageing. Clin Exp Immunol. 1998; 112: 48-51.

77. Bandrés E, Merino J, Vázquez B, Inogés S, Moreno C, Subirá ML, Sánchez-Ibarrola A. The increase of IFNgamma production through aging correlates with the expanded CD8(+high)CD28(-)CD57(+) subpopulation. Clin Immunol. 2000; 96: 230-5.

78. Focosi D, Bestagno M, Burrone O, Petrini M. CD57+ T lymphocytes and functional immune deficiency. J Leukoc Biol. 2010; 87: 107-16.

79. Uusitalo M, Kivelä T. The HNK-1 carbohydrate epitope in the eye: basic science and functional implications. Prog Retin Eye Res. 2001; 20: 1-28.

80. Filaci G, Fenoglio D, Fravega M, Ansaldo G, Borgonovo G, Traverso P, Villaggio B, Ferrera A, Kunkl A, Rizzi M, Ferrera F, Balestra P, Ghio M, et al. CD8+ CD28- T regulatory lymphocytes inhibiting $\mathrm{T}$ cell proliferative and cytotoxic functions infiltrate human cancers. J Immunol. 2007; 179: 4323-34.

81. Casado JG, Soto R, DelaRosa O, Peralbo E, del Carmen Muñoz-Villanueva M, Rioja L, Peña J, Solana R, Tarazona R. CD8 T cells expressing NK associated receptors are increased in melanoma patients and display an effector phenotype. Cancer Immunol Immunother. 2005; 54: 1162 71.

82. Meloni F, Morosini M, Solari N, Passadore I, Nascimbene C, Novo M, Ferrari M, Cosentino M, Marino F, Pozzi E, Fietta AM. Foxp3 expressing CD4+ CD25+ and CD8+CD28- $T$ regulatory cells in the peripheral blood of patients with lung cancer and pleural mesothelioma. Hum Immunol.2006; 67: 1-12.
83. Characiejus D, Pasukoniene V, Jonusauskaite R, Azlauskaite N, Aleknavicius E, Mauricas M, Otter W Den. Peripheral blood CD8highCD57+ lymphocyte levels may predict outcome in melanoma patients treated with adjuvant interferon-alpha. Anticancer Res.; 28: 1139-42.

84. Urbaniak-Kujda D, Kapelko-Słowik K, Wołowiec D, Dybko J, Hałoń A, Jaźwiec B, Maj J, Jankowska-Konsur A, Kuliczkowski K. Increased percentage of CD8+CD28suppressor lymphocytes in peripheral blood and skin infiltrates correlates with advanced disease in patients with cutaneous T-cell lymphomas. Postepy Hig Med Dosw (Online). 2009; 63: 355-9.

85. Frassanito MA, Silvestris F, Cafforio P, Dammacco F. CD8+/CD57 cells and apoptosis suppress T-cell functions in multiple myeloma. Br J Haematol. 1998; 100: 469-77.

86. Focosi D, Petrini M. CD57 expression on lymphoma microenvironment as a new prognostic marker related to immune dysfunction. J Clin Oncol. 2007; 25: 1289-91; author reply 1291-2.

87. Serrano D, Monteiro J, Allen SL, Kolitz J, Schulman P, Lichtman SM, Buchbinder A, Vinciguerra VP, Chiorazzi N, Gregersen PK. Clonal expansion within the CD4+CD57+ and CD8+CD57+ T cell subsets in chronic lymphocytic leukemia. J Immunol. 1997; 158: 1482-9.

88. Vidriales MB, Orfao A, López-Berges MC, González M, Hernandez JM, Ciudad J, López A, Moro MJ, Martínez M, San Miguel JF. Lymphoid subsets in acute myeloid leukemias: increased number of cells with NK phenotype and normal T-cell distribution. Ann Hematol. 1993; 67: $217-22$.

89. Dianzani U, Funaro A, DiFranco D, Garbarino G, Bragardo M, Redoglia V, Buonfiglio D, De Monte LB, Pileri A, Malavasi F. Interaction between endothelium and CD4+CD45RA+ lymphocytes. Role of the human CD38 molecule. J Immunol. 1994; 153: 952-9.

90. Funaro A, Ferrero E, Mehta K, Malavasi F. Schematic portrait of human CD38 and related molecules. Chem Immunol. 2000; 75: 256-73.

91. Howard M, Grimaldi JC, Bazan JF, Lund FE, SantosArgumedo L, Parkhouse RM, Walseth TF, Lee HC. Formation and hydrolysis of cyclic ADP-ribose catalyzed by lymphocyte antigen CD38. Science. 1993; 262: 1056-9.

92. Fernàndez JE, Deaglio S, Donati D, Beusan IS, Corno F, Aranega A, Forni M, Falini B, Malavasi F. Analysis of the distribution of human CD38 and of its ligand CD31 in normal tissues. J Biol Regul Homeost Agents. 1998; 12: 81-91.

93. Cesano A, Visonneau S, Deaglio S, Malavasi F, Santoli D. Role of CD38 and its ligand in the regulation of MHCnonrestricted cytotoxic T cells. J Immunol. 1998; 160: 1106-15.

94. Konoplev S, Medeiros LJ, Bueso-Ramos CE, Jorgensen JL, Lin P. Immunophenotypic profile of lymphoplasmacytic lymphoma/Waldenström macroglobulinemia. Am J Clin 
Pathol. 2005; 124: 414-20.

95. Parry-Jones N, Matutes E, Morilla R, Brito-Babapulle V, Wotherspoon A, Swansbury GJ, Catovsky D. Cytogenetic abnormalities additional to $\mathrm{t}(11 ; 14)$ correlate with clinical features in leukaemic presentation of mantle cell lymphoma, and may influence prognosis: a study of 60 cases by FISH. Br J Haematol. 2007; 137: 117-24.

96. Keyhani A, Huh YO, Jendiroba D, Pagliaro L, Cortez J, Pierce S, Pearlman M, Estey E, Kantarjian H, Freireich EJ. Increased CD38 expression is associated with favorable prognosis in adult acute leukemia. Leuk Res. 2000; 24: 153-9.

97. Marinov J, Koubek K, Starý J. Immunophenotypic significance of the \&quot;lymphoid\&quot; CD38 antigen in myeloid blood malignancies. Neoplasma. 1993; 40: 355-8.

98. Wang L, Wang H, Li P, Lu Y, Xia Z, Huang H, Zhang Y. CD38 expression predicts poor prognosis and might be a potential therapy target in extranodal NK/T cell lymphoma, nasal type. Ann Hematol. 2015; 94: 1381-8.

99. Lin P, Owens R, Tricot G, Wilson CS. Flow cytometric immunophenotypic analysis of 306 cases of multiple myeloma. Am J Clin Pathol. 2004; 121: 482-8.

100. de Weers M, Tai Y-T, van der Veer MS, Bakker JM, Vink T, Jacobs DCH, Oomen LA, Peipp M, Valerius T, Slootstra JW, Mutis T, Bleeker WK, Anderson KC, et al. Daratumumab, a novel therapeutic human CD38 monoclonal antibody, induces killing of multiple myeloma and other hematological tumors. J Immunol. 2011; 186: 1840-8.

101. Krejcik J, Casneuf T, Nijhof IS, Verbist B, Bald J, Plesner T, Syed K, Liu K, van de Donk NWCJ, Weiss BM, Ahmadi T, Lokhorst HM, Mutis T, et al. Daratumumab depletes $\mathrm{CD} 38+$ immune regulatory cells, promotes T-cell expansion, and skews T-cell repertoire in multiple myeloma. Blood. 2016; 128: 384-94.

102. van der Veer MS, de Weers M, van Kessel B, Bakker JM, Wittebol S, Parren PWHI, Lokhorst HM, Mutis T. Towards effective immunotherapy of myeloma: enhanced elimination of myeloma cells by combination of lenalidomide with the human CD38 monoclonal antibody daratumumab. Haematologica. 2011; 96: 284-90.

103. van der Veer MS, de Weers M, van Kessel B, Bakker JM, Wittebol S, Parren PWHI, Lokhorst HM, Mutis T. The therapeutic human CD38 antibody daratumumab improves the anti-myeloma effect of newly emerging multi-drug therapies. Blood Cancer J. 2011; 1: e41.

104. Palumbo A, Chanan-Khan A, Weisel K, Nooka AK, Masszi T, Beksac M, Spicka I, Hungria V, Munder M, Mateos M V, Mark TM, Qi M, Schecter J, et al. Daratumumab, Bortezomib, and Dexamethasone for Multiple Myeloma. N Engl J Med. 2016; 375: 754-66.

105. Dimopoulos MA, Oriol A, Nahi H, San-Miguel J, Bahlis NJ, Usmani SZ, Rabin N, Orlowski RZ, Komarnicki M, Suzuki K, Plesner T, Yoon S-S, Ben Yehuda D, et al.
Daratumumab, Lenalidomide, and Dexamethasone for Multiple Myeloma. N Engl J Med. 2016; 375: 1319-31.

106. Freeman GJ, Long AJ, Iwai Y, Bourque K, Chernova T, Nishimura H, Fitz LJ, Malenkovich N, Okazaki T, Byrne MC, Horton HF, Fouser L, Carter L, et al. Engagement of the PD-1 immunoinhibitory receptor by a novel B7 family member leads to negative regulation of lymphocyte activation. J Exp Med. 2000; 192: 1027-34.

107. Dong H, Strome SE, Salomao DR, Tamura H, Hirano F, Flies DB, Roche PC, Lu J, Zhu G, Tamada K, Lennon VA, Celis E, Chen L. Tumor-associated B7-H1 promotes T-cell apoptosis: a potential mechanism of immune evasion. Nat Med. 2002; 8: 793-800.

108. Parry R V, Chemnitz JM, Frauwirth KA, Lanfranco AR, Braunstein I, Kobayashi S V, Linsley PS, Thompson CB, Riley JL. CTLA-4 and PD-1 receptors inhibit T-cell activation by distinct mechanisms. Mol Cell Biol. 2005; 25: 9543-53.

109. Spranger S, Spaapen RM, Zha Y, Williams J, Meng Y, Ha TT, Gajewski TF. Up-regulation of PD-L1, IDO, and $\mathrm{T}$ (regs) in the melanoma tumor microenvironment is driven by CD8(+) T cells. Sci Transl Med. 2013; 5: 200 ra116.

110. Taube JM, Klein A, Brahmer JR, Xu H, Pan X, Kim JH, Chen L, Pardoll DM, Topalian SL, Anders RA. Association of PD-1, PD-1 ligands, and other features of the tumor immune microenvironment with response to anti-PD-1 therapy. Clin Cancer Res. 2014; 20: 5064-74.

111. Liu J, Hamrouni A, Wolowiec D, Coiteux V, Kuliczkowski K, Hetuin D, Saudemont A, Quesnel B. Plasma cells from multiple myeloma patients express B7-H1 (PD-L1) and increase expression after stimulation with IFN-\{gamma\} and TLR ligands via a MyD88-, TRAF6-, and MEKdependent pathway. Blood. 2007; 110: 296-304.

112. Tamura H, Ishibashi $M$, Yamashita $T$, Tanosaki $S$, Okuyama N, Kondo A, Hyodo H, Shinya E, Takahashi H, Dong H, Tamada K, Chen L, Dan K, et al. Marrow stromal cells induce B7-H1 expression on myeloma cells, generating aggressive characteristics in multiple myeloma. Leukemia. 2013; 27: 464-72.

113. Paiva B, Azpilikueta A, Puig N, Ocio EM, Sharma R, Oyajobi BO, Labiano S, San-Segundo L, Rodriguez A, Aires-Mejia I, Rodriguez I, Escalante F, de Coca AG, et al. PD-L1/PD-1 presence in the tumor microenvironment and activity of PD-1 blockade in multiple myeloma. Leukemia. 2015; 29: 2110-3.

114. Ray A, Das DS, Song Y, Richardson P, Munshi NC, Chauhan D, Anderson KC. Targeting PD1-PDL1 immune checkpoint in plasmacytoid dendritic cell interactions with $\mathrm{T}$ cells, natural killer cells and multiple myeloma cells. Leukemia. 2015;29:1441-4.

115. Sponaas A-M, Moharrami NN, Feyzi E, Standal T, Holth Rustad E, Waage A, Sundan A. PDL1 Expression on Plasma and Dendritic Cells in Myeloma Bone Marrow Suggests Benefit of Targeted anti PD1-PDL1 Therapy. PLoS One. 2015; 10: e0139867. 
116. Lesokhin AM, Ansell SM, Armand P, Scott EC, Halwani A, Gutierrez M, Millenson MM, Cohen AD, Schuster SJ, Lebovic D, Dhodapkar M, Avigan D, Chapuy B, et al. Nivolumab in Patients With Relapsed or Refractory Hematologic Malignancy: Preliminary Results of a Phase Ib Study. J Clin Oncol. 2016; 34: 2698-704.

117. Berger R, Rotem-Yehudar R, Slama G, Landes S, Kneller A, Leiba M, Koren-Michowitz M, Shimoni A, Nagler A. Phase I safety and pharmacokinetic study of CT-011, a humanized antibody interacting with PD-1, in patients with advanced hematologic malignancies. Clin Cancer Res. 2008; 14: 3044-51.

118. Vacca A, Ribatti D, Presta M, Minischetti M, Iurlaro M, Ria R, Albini A, Bussolino F, Dammacco F. Bone marrow neovascularization, plasma cell angiogenic potential, and matrix metalloproteinase-2 secretion parallel progression of human multiple myeloma. Blood. 1999; 93: 3064-73.

119. Zingone A, Kuehl WM. Pathogenesis of monoclonal gammopathy of undetermined significance and progression to multiple myeloma. Semin Hematol. 2011; 48: 4-12.

120. Conn G, Bayne ML, Soderman DD, Kwok PW, Sullivan KA, Palisi TM, Hope DA, Thomas KA. Amino acid and cDNA sequences of a vascular endothelial cell mitogen that is homologous to platelet-derived growth factor. Proc Natl Acad Sci U S A. 1990; 87: 2628-32.

121. Senger DR, Connolly DT, Van de Water L, Feder J, Dvorak HF. Purification and NH2-terminal amino acid sequence of guinea pig tumor-secreted vascular permeability factor. Cancer Res. 1990; 50: 1774-8.

122. Maglione D, Guerriero V, Viglietto G, Delli-Bovi P, Persico MG. Isolation of a human placenta cDNA coding for a protein related to the vascular permeability factor. Proc Natl Acad Sci U S A. 1991; 88: 9267-71.

123. Maglione D, Guerriero V, Viglietto G, Ferraro MG, Aprelikova O, Alitalo K, Del Vecchio S, Lei KJ, Chou JY, Persico MG. Two alternative mRNAs coding for the angiogenic factor, placenta growth factor (PlGF), are transcribed from a single gene of chromosome 14. Oncogene. 1993; 8: 925-31.

124. Olofsson B, Pajusola K, Kaipainen A, von Euler G, Joukov V, Saksela O, Orpana A, Pettersson RF, Alitalo K, Eriksson U. Vascular endothelial growth factor B, a novel growth factor for endothelial cells. Proc Natl Acad Sci U S A. 1996; 93: 2576-81.

125. Joukov V, Pajusola K, Kaipainen A, Chilov D, Lahtinen I, Kukk E, Saksela O, Kalkkinen N, Alitalo K. A novel vascular endothelial growth factor, VEGF-C, is a ligand for the Flt4 (VEGFR-3) and KDR (VEGFR-2) receptor tyrosine kinases. EMBO J. 1996; 15: 290-8.

126. Achen MG, Jeltsch M, Kukk E, Mäkinen T, Vitali A, Wilks AF, Alitalo K, Stacker SA. Vascular endothelial growth factor D (VEGF-D) is a ligand for the tyrosine kinases VEGF receptor 2 (Flk1) and VEGF receptor 3 (Flt4). Proc Natl Acad Sci U S A. 1998; 95: 548-53.
127. Abu-Jawdeh GM, Faix JD, Niloff J, Tognazzi K, Manseau E, Dvorak HF, Brown LF. Strong expression of vascular permeability factor (vascular endothelial growth factor) and its receptors in ovarian borderline and malignant neoplasms. Lab Invest. 1996; 74: 1105-15.

128. Davis-Smyth T, Chen H, Park J, Presta LG, Ferrara N. The second immunoglobulin-like domain of the VEGF tyrosine kinase receptor Flt-1 determines ligand binding and may initiate a signal transduction cascade. EMBO J. 1996; 15: 4919-27.

129. Browder TM, Dunbar CE, Nienhuis AW. Private and public autocrine loops in neoplastic cells. Cancer Cells. 1989; 1: 9-17.

130. Wang GL, Semenza GL. Purification and characterization of hypoxia-inducible factor 1. J Biol Chem. 1995; 270: 1230-7.

131. Iliopoulos O, Levy AP, Jiang C, Kaelin WG, Goldberg MA. Negative regulation of hypoxia-inducible genes by the von Hippel-Lindau protein. Proc Natl Acad Sci U S A. 1996; 93 : 10595-9.

132. Palumbo AP, Pileri A, Dianzani U, Massaia M, Boccadoro M, Calabretta B. Altered expression of growth-regulated protooncogenes in human malignant plasma cells. Cancer Res. 1989; 49: 4701-4.

133. Wood JM, Bold G, Buchdunger E, Cozens R, Ferrari S, Frei J, Hofmann F, Mestan J, Mett H, O’Reilly T, Persohn E, Rösel J, Schnell C, et al. PTK787/ZK 222584, a novel and potent inhibitor of vascular endothelial growth factor receptor tyrosine kinases, impairs vascular endothelial growth factor-induced responses and tumor growth after oral administration. Cancer Res. 2000; 60: 2178-89.

134. Pruneri G, Ponzoni M, Ferreri AJM, Decarli N, Tresoldi M, Raggi F, Baldessari C, Freschi M, Baldini L, Goldaniga M, Neri A, Carboni N, Bertolini F, et al. Microvessel density, a surrogate marker of angiogenesis, is significantly related to survival in multiple myeloma patients. Br J Haematol. 2002; 118: 817-20.

135. Dales J-P, Garcia S, Bonnier P, Duffaud F, Carpentier S, Djemli A, Ramuz O, Andrac L, Lavaut M, Allasia C, Charpin C. [Prognostic significance of VEGF receptors, VEGFR-1 (Flt-1) and VEGFR-2 (KDR/Flk-1) in breast carcinoma]. Ann Pathol. 2003; 23: 297-305.

136. Wu Y, Hooper AT, Zhong Z, Witte L, Bohlen P, Rafii S, Hicklin DJ. The vascular endothelial growth factor receptor (VEGFR-1) supports growth and survival of human breast carcinoma. Int J cancer. 2006; 119: 1519-29.

137. Ferrara N, Hillan KJ, Novotny W. Bevacizumab (Avastin), a humanized anti-VEGF monoclonal antibody for cancer therapy. Biochem Biophys Res Commun. 2005; 333: 328 35.

138. Gorski DH, Beckett MA, Jaskowiak NT, Calvin DP, Mauceri HJ, Salloum RM, Seetharam S, Koons A, Hari DM, Kufe DW, Weichselbaum RR. Blockage of the vascular endothelial growth factor stress response increases 
the antitumor effects of ionizing radiation. Cancer Res. 1999; 59: 3374-8.

139. Hoyer RJ, Leung N, Witzig TE, Lacy MQ. Treatment of diuretic refractory pleural effusions with bevacizumab in four patients with primary systemic amyloidosis. Am J Hematol. 2007; 82: 409-13.

140. Goldman B. For investigational targeted drugs, combination trials pose challenges. J Natl Cancer Inst. 2003; 95: 1744-6.

141. Somlo G, Lashkari A, Bellamy W, Zimmerman TM, Tuscano JM, O'Donnell MR, Mohrbacher AF, Forman SJ, Frankel P, Chen HX, Doroshow JH, Gandara DR. Phase II randomized trial of bevacizumab versus bevacizumab and thalidomide for relapsed/refractory multiple myeloma: a California Cancer Consortium trial. Br J Haematol. 2011; 154: 533-5.

142. Yancopoulos GD, Davis S, Gale NW, Rudge JS, Wiegand SJ, Holash J. Vascular-specific growth factors and blood vessel formation. Nature. 2000; 407: 242-8.

143. Thurston G. Complementary actions of VEGF and angiopoietin-1 on blood vessel growth and leakage. J Anat. 2002; 200: 575-80.

144. Scharpfenecker M, Fiedler U, Reiss Y, Augustin HG. The Tie-2 ligand angiopoietin-2 destabilizes quiescent endothelium through an internal autocrine loop mechanism. J Cell Sci. 2005; 118: 771-80.

145. Nakayama T, Yao L, Tosato G. Mast cell-derived angiopoietin-1 plays a critical role in the growth of plasma cell tumors. J Clin Invest. 2004; 114: 1317-25.

146. Giuliani N, Colla S, Lazzaretti M, Sala R, Roti G, Mancini C, Bonomini S, Lunghi P, Hojden M, Genestreti G, Svaldi M, Coser P, Fattori PP, et al. Proangiogenic properties of human myeloma cells: production of angiopoietin- 1 and its potential relationship to myeloma-induced angiogenesis. Blood. 2003; 102: 638-45.

147. Pappa CA, Alexandrakis MG, Boula A, Thanasia A, Konsolas I, Alegakis A, Tsirakis G. Prognostic impact of angiopoietin-2 in multiple myeloma. J Cancer Res Clin Oncol. 2014; 140: 1801-5.

148. Greco C, D’Agnano I, Vitelli G, Vona R, Marino M, Mottolese M, Zuppi C, Capoluongo E, Ameglio F. c-MYC deregulation is involved in melphalan resistance of multiple myeloma: role of PDGF-BB. Int J Immunopathol Pharmacol. 2006; 19: 67-79.

149. Dong X, Han ZC, Yang R. Angiogenesis and antiangiogenic therapy in hematologic malignancies. Crit Rev Oncol Hematol. 2007; 62: 105-18.

150. Tsirakis G, Pappa CA, Kanellou P, Stratinaki MA, Xekalou A, Psarakis FE, Sakellaris G, Alegakis A, Stathopoulos EN, Alexandrakis MG. Role of platelet-derived growth factor$\mathrm{AB}$ in tumour growth and angiogenesis in relation with other angiogenic cytokines in multiple myeloma. Hematol Oncol. 2012; 30: 131-6.

151. Liu Y, Poon RT, Li Q, Kok TW, Lau C, Fan ST. Both antiangiogenesis- and angiogenesis-independent effects are responsible for hepatocellular carcinoma growth arrest by tyrosine kinase inhibitor PTK787/ZK222584. Cancer Res. 2005; 65: 3691-9.

152. Liu Y, Wen XM, Lui ELH, Friedman SL, Cui W, Ho NPS, Li L, Ye T, Fan ST, Zhang H. Therapeutic targeting of the PDGF and TGF-beta-signaling pathways in hepatic stellate cells by PTK787/ZK22258. Lab Invest. 2009; 89: 1152-60.

153. Otsuki T, Yamada O, Yata K, Sakaguchi H, Kurebayashi J, Nakazawa N, Taniwaki M, Yawata Y, Ueki A. Expression of fibroblast growth factor and FGF-receptor family genes in human myeloma cells, including lines possessing $\mathrm{t}(4 ; 14)$ (q16.3;q32. 3) and FGFR3 translocation. Int J Oncol. 1999; 15: 1205-12.

154. Rajkumar S V, Leong T, Roche PC, Fonseca R, Dispenzieri A, Lacy MQ, Lust JA, Witzig TE, Kyle RA, Gertz MA, Greipp PR. Prognostic value of bone marrow angiogenesis in multiple myeloma. Clin Cancer Res. 2000; 6: 3111-6.

155. Bisping G, Leo R, Wenning D, Dankbar B, Padró T, Kropff M, Scheffold C, Kröger M, Mesters RM, Berdel WE, Kienast J. Paracrine interactions of basic fibroblast growth factor and interleukin-6 in multiple myeloma. Blood. 2003; 101: 2775-83.

156. MacNaul KL, Chartrain N, Lark M, Tocci MJ, Hutchinson NI. Discoordinate expression of stromelysin, collagenase, and tissue inhibitor of metalloproteinases-1 in rheumatoid human synovial fibroblasts. Synergistic effects of interleukin-1 and tumor necrosis factor-alpha on stromelysin expression. J Biol Chem. 1990; 265: 17238-45.

157. Rifas L, Fausto A, Scott MJ, Avioli L V, Welgus HG. Expression of metalloproteinases and tissue inhibitors of metalloproteinases in human osteoblastlike cells: differentiation is associated with repression of metalloproteinase biosynthesis. Endocrinology. 1994; 134: 213-21.

158. Bergers G, Song S, Meyer-Morse N, Bergsland E, Hanahan D. Benefits of targeting both pericytes and endothelial cells in the tumor vasculature with kinase inhibitors. J Clin Invest. 2003; 111: 1287-95.

159. Barillé S, Akhoundi C, Collette M, Mellerin MP, Rapp MJ, Harousseau JL, Bataille R, Amiot M. Metalloproteinases in multiple myeloma: production of matrix metalloproteinase-9 (MMP-9), activation of proMMP-2, and induction of MMP1 by myeloma cells. Blood. 1997; 90: 1649-55.

160. D'Armiento J, Dalal SS, Okada Y, Berg RA, Chada K. Collagenase expression in the lungs of transgenic mice causes pulmonary emphysema. Cell. 1992; 71: 955-61.

161. Ray JM, Stetler-Stevenson WG. Gelatinase A activity directly modulates melanoma cell adhesion and spreading. EMBO J. 1995; 14: 908-17.

162. Conway JG, Wakefield JA, Brown RH, Marron BE, Sekut L, Stimpson SA, McElroy A, Menius JA, Jeffreys JJ, Clark RL. Inhibition of cartilage and bone destruction in adjuvant arthritis in the rat by a matrix metalloproteinase inhibitor. $\mathrm{J}$ Exp Med. 1995; 182: 449-57. 
163. Wojtowicz-Praga S, Low J, Marshall J, Ness E, Dickson R, Barter J, Sale M, McCann P, Moore J, Cole A, Hawkins MJ. Phase I trial of a novel matrix metalloproteinase inhibitor batimastat (BB-94) in patients with advanced cancer. Invest New Drugs. 1996; 14: 193-202.

164. Macaulay VM, O’Byrne KJ, Saunders MP, Braybrooke JP, Long L, Gleeson F, Mason CS, Harris AL, Brown P, Talbot DC. Phase I study of intrapleural batimastat (BB94), a matrix metalloproteinase inhibitor, in the treatment of malignant pleural effusions. Clin Cancer Res. 1999; 5: 513-20.

165. Nagata S, Tsuchiya M, Asano S, Kaziro Y, Yamazaki T, Yamamoto O, Hirata Y, Kubota N, Oheda M, Nomura H. Molecular cloning and expression of cDNA for human granulocyte colony-stimulating factor. Nature. 1986; 319 : 415-8.

166. Souza LM, Boone TC, Gabrilove J, Lai PH, Zsebo KM, Murdock DC, Chazin VR, Bruszewski J, Lu H, Chen KK. Recombinant human granulocyte colony-stimulating factor: effects on normal and leukemic myeloid cells. Science. 1986; 232: 61-5.

167. Yan B, Wei J-J, Yuan Y, Sun R, Li D, Luo J, Liao S-J, Zhou Y-H, Shu Y, Wang Q, Zhang G-M, Feng Z-H. IL-6 cooperates with G-CSF to induce protumor function of neutrophils in bone marrow by enhancing STAT3 activation. J Immunol. 2013; 190: 5882-93.

168. Howard M, O'Garra A, Ishida H, de Waal Malefyt R, de Vries J. Biological properties of interleukin 10. J Clin Immunol. 1992; 12: 239-47.
169. Alexandrakis MG, Goulidaki N, Pappa CA, Boula A, Psarakis F, Neonakis I, Tsirakis G. Interleukin-10 Induces Both Plasma Cell Proliferation and Angiogenesis in Multiple Myeloma. Pathol Oncol Res. 2015 ; 21: 929-34.

170. Holland G, Zlotnik A. Interleukin-10 and cancer. Cancer Invest. 1993 ; 11: 751-8.

171. Muthu Raja KR, Kubiczkova L, Rihova L, Piskacek M, Vsianska P, Hezova R, Pour L, Hajek R. Functionally suppressive CD8 T regulatory cells are increased in patients with multiple myeloma: a cause for immune impairment. PLoS One. 2012; 7: e49446.

172. Nguyen-Pham T-N, Lee Y-K, Kim H-J, Lee J-J. Immunotherapy using dendritic cells against multiple myeloma: how to improve? Clin Dev Immunol. 2012; 2012: 397648.

173. Stassi G, Todaro M, Zerilli M, Ricci-Vitiani L, Di Liberto D, Patti M, Florena A, Di Gaudio F, Di Gesù G, De Maria $\mathrm{R}$. Thyroid cancer resistance to chemotherapeutic drugs via autocrine production of interleukin-4 and interleukin-10. Cancer Res . 2003; 63: 6784-90.

174. Gupta M, Han JJ, Stenson M, Maurer M, Wellik L, Hu G, Ziesmer S, Dogan A, Witzig TE. Elevated serum IL-10 levels in diffuse large B-cell lymphoma: a mechanism of aberrant JAK2 activation. Blood. 2012; 119: 2844-53.

175. Wang H, Wang L, Chi P-D, Wang W, Chen X-Q, Geng Q-R, Xia Z-J, Lu Y. High level of interleukin-10 in serum predicts poor prognosis in multiple myeloma. Br J Cancer. 2016; 114: 463-8. 